Hydroécol. Appl. (1995) Tome 7 Vol. 1-2, pp. 185-190

\title{
Installation de l'Amphipode Corophium curvispinum et de la palourde asiatique Corbicula sp. dans la partie française de la Moselle
}

\section{Establishment of the Amphipod Corophium curvispinum and the Asiatic Clam Corbicula sp. in the French part of the Mosel river}

\author{
V. Bachmann, E. Cegielka, P. Wagner, \\ P. Usseglio-Polatera et J.-C. Moreteau(1) \\ (1) Equipe de Démoécologie. Centre de Recherches Ecologiques. Université de Metz. 1, rue \\ des Recollets 57000 Metz.
}

Résumé. - L'Amphipode Corophium curvispinum et la Palourde Asiatique Corbicula sp., deux nouveaux immigrants du fleuve Rhin, ont été collectés par dragage à une profondeur de 1 à 4 mètres dans le cours français de la Moselle. Ils sont déjà présents sur au moins $287 \mathrm{~km}$ de cours depuis l'embouchure pour C. curvispinum et $337 \mathrm{~km}$ pour Corbicula $\mathrm{sp}$. La distribution de ces espèces nouvellement immigrées semble être en relation avec la nature du substrat. La dynamique des populations de ces nouvelles espèces invasives, qui se sont déjà imposées comme deux des principaux taxa dans la Moselle, et leur possible impact sur les communautés zoobenthiques exigent un suivi attentif dans cet écosystème.

Mots-clés. - Corophium curispinum, Corbicula, distribution, densité, Moselle.

\begin{abstract}
The amphipod Corophium curvispinum and the asiatic clam Corbicula sp., two new immigrants from the Rhine River, have been collected from dredging at a water depth of 1-4 meters in the French part of the Mosel River. They are already distributed over at least $287 \mathrm{~km}$ for C. curvispinum and $337 \mathrm{~km}$ for Corbicula sp. from the mouth of the river. The distributions of those new species appear to be related to the bottom substrate type. The population dynamics of those new mass invaders in this ecosystem, that are already two of the prevailing taxa in the Mosel River, and their possible impact on zoobenthic communities must be carefully observed.
\end{abstract}

Key words. - Corophium curvispinum, Corbicula, distribution, densities, Mosel River. 


\section{INTRODUCTION}

The invasion of the zebra mussel Dreissena polymorpha from the Caspian Sea basin into western Europe started two centuries ago. This species is now a common freshwater bivalve in the major European rivers (Hebert et al., 1989; Van der Velde et al., 1994). The amphipod Corophium curvispinum Sars, 1895 has been expanding its distributional range from the same area since the beginning of the 20th century into Europe, via various river systems and interconnecting canals. This species was discovered for the first time in the Rhine River in 1987 and nowadays C. curvispinum is by far the most dominant macroinvertebrate species in the Dutch part of this river (Paffen et al., 1994). Since 1988, a population of more than ten thousand individuals per meter square have been established in the mouth of the Mosel River (Schöll, 1990). The species was mentioned in 1993 up to Remich in Luxembourg at the pK 229.5 ( $\mathrm{pK}=$ navigation kilometric point). This locality was considered as the upper limit of its distribution area (Dhur \& Massard, 1995).

Clams of the genus Corbicula are native to Asia, Africa and Australia where they form an important component of the benthic community (McMahon, 1983). Corbicula fluminea was introduced at the beginning of the century in the United-States where it spred in an explosive fashion, causing considerable damage to hydroinstallations and becoming one of the most important molluscan pest species ever introduced into the USA (McMahon, 1983). At the present time, there is still some confusion about the names and the number of Corbicula species that have been involved in the colonization of the European rivers, and a diagnosis of the exact species remains somewhat dubious. Corbicula (e.g. fluminalis) was recorded in 1980 in the Dordogne River (South-Western France), in the Tage River (Portugal) (Mouthon, 1981), and in 1984 in the Tidal Weser River (N. Germany) (Haesloop, 1992). Two forms (e.g. fluminea and/or fluminalis), or species (e.g. fluminea and fluviatilis) have been established in a large part of the Rhine River system since 1987 (Kinzelbach, 1991; Den Hartog et al., 1992). Kinzelbach (1991) noticed that both Corbicula species had arrived in Europe via ships carrying ballast water from the south of North-America. Corbicula was not recorded in the Mosel River until now (Dhur \& Massard, 1995).

Since 1994, a research program has been carried out on the Mosel River in order to investigate the distribution area and the local density of the new filter-feeder invaders Corophium curvispinum and Corbicula sp.. These patterns will be compared to the distribution and the density of Dreissena polymorpha still established for many years in this river.

\section{MATERIALS AND METHODS}

Samples of macroinvertebrates have been performed at a water depth 
of 1-4 meters by means of two benthic dredges used according to the particle size of the bottom substrate of each sampling site. A triangular dredge with a $39 \mathrm{~cm}$ side lenght (see Berly, 1989 for further details), and a cylindrical dredge Rallier du Baty's type with an opening diameter of $30 \mathrm{~cm}$ were used from a boat on eight stations of the Mosel River from Grevenmacher (pK 211.0) to Gondreville (pK 367.0) (fig. 1). Samples were taken as much as possible on the left bank, on the channel and on the right bank. The surface area of the sampled bottom was estimated in the way described by Berly (1989). The materials collected, including macroinvertebrates, were put into plastic jars and preserved in $70 \%$ ethanol. In laboratory, the specimens of Dreissena polymorpha, Corbicula sp. and Corophium curvispinum were sorted out, counted and preserved in $70 \%$ ethanol for later identification. The granulometric structure of each substrate sample was also estimated by sifting particulate materials after drying for $24 \mathrm{~h}$ at $105^{\circ} \mathrm{C}$. Six granulometric fractions were considered : $0.5-4 \mathrm{~mm}$ : sand; $4-8 \mathrm{~mm}$ : coarse sand/fine gravel; $8-32 \mathrm{~mm}$ : gravel/small pebbles; $32-64 \mathrm{~mm}$ : pebbles; $64-128 \mathrm{~mm}$ : cobbles $>128 \mathrm{~mm}$ : boulders.

\section{RESULTS AND DISCUSSION}

The analysis of macrobenthic populations in a first campaign of dredging (july and september 1994) demonstrated the expansion of Corbicula sp. and Corophium cur- vispinum in the river Mosel. C. curvispinum is well established at Grevenmacher. Its density reached up 97,000 ind. $\mathrm{m}^{-2}$. This species appears to be, with Dreissena polymorpha (maximum of 65,909 ind. $\mathrm{m}^{-2}$ ), one of the dominant species of this station (Table I). The densities of $C$. curvispinum are less important in the 'natural' sector of Hauconcourt (pK 286.0) with a maximum of 925 ind. $m^{-2}\left(19,358\right.$ ind. $m^{-2}$ for $D$. polymorpha). Two hypotheses may be envisioned. Firstly, Hauconcourt might be the present geographical upper limit of the $C$. curvispinum expansion. Secondly, the finest granulometric structure of the bottom at this station do not promote the settlement of this burrowing species that preferentially live in muddy tubes on hard substrates. Recent researches (Bachmann, unpubl.) tend to assess this last hypothesis. As reported by Den Hartog et al. (1992), Corbicula sp. prefers coarse sand or fine gravel (142 to 8,760 ind. $\mathrm{m}^{-2}$ at Hauconcourt) to cobbles or boulders ( 0 to 17 ind. $\mathrm{m}^{-2}$ at Grevenmacher).

The previous data show that Corbicula sp. could be the prevailing taxa in the Mosel River at Hauconcourt. Further spatial investigations revealed that Corbicula sp. was present up to Dieulouard ( $p K 337.0$ ) with a density of only 5 to 7 ind. $\mathrm{m}^{-2}$, but was not catched at Gondreville (pK 367.0) until december 1994 (Table II).

Two morphological forms or species of Corbicula have been collected. The most important densities were observed in a mixture of gravel and 


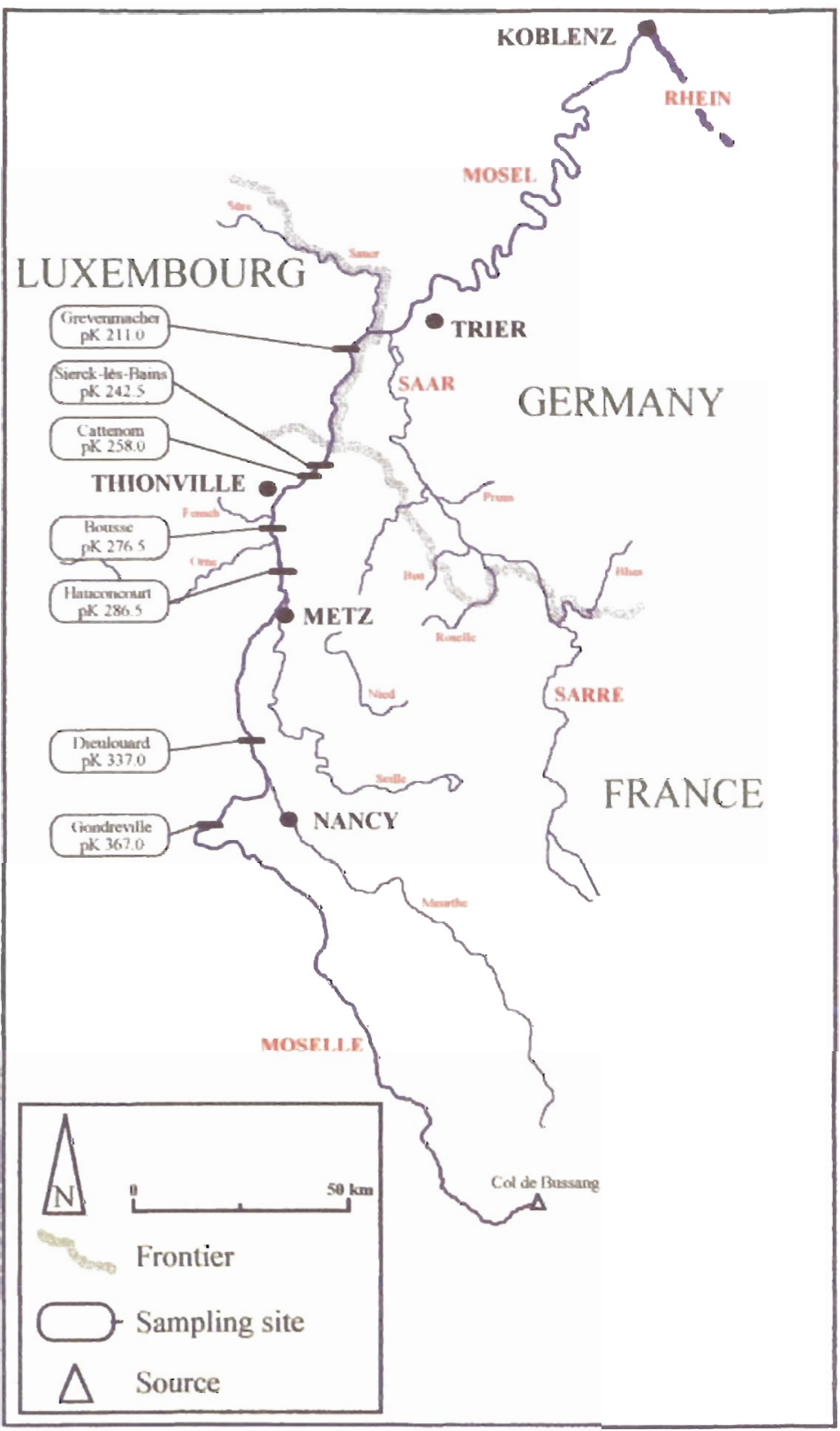

Fig. 1. - Map of the sampling sites on the Mosel River. pK refers to navigation kilometric point. 
Table I. - Densities of Dreissena polymorpha, Corbicula sp. and Corophium curvispinum (ind. $\mathrm{m}^{-2}$ ) sampled in t'? concourt (France) according to the substrate type during summer and autumn 1994. pK corresponds to navigation kilometric point.

\begin{tabular}{|c|c|c|c|c|c|c|c|}
\hline \multirow[t]{2}{*}{ Date } & \multirow[t]{2}{*}{ Station } & \multirow[t]{2}{*}{ pK } & \multirow{2}{*}{$\begin{array}{c}\text { Transversal } \\
\text { location }\end{array}$} & \multicolumn{3}{|c|}{ Density (ind. $m^{-2}$ ) } & \multirow[t]{2}{*}{ Substrate type } \\
\hline & & & & Dreissena & Corbicula & Corophium & \\
\hline $07 / 94$ & $\begin{array}{l}\text { Grevenmacher } \\
\text { Grevenmacher }\end{array}$ & $\begin{array}{l}211.0 \\
211.2\end{array}$ & $\begin{array}{l}\text { Left Bank } \\
\text { Channel }\end{array}$ & $\begin{array}{l}35672 \\
11765\end{array}$ & $\begin{array}{r}17 \\
0\end{array}$ & $\begin{array}{r}97552 \\
2955\end{array}$ & $\begin{array}{l}\text { Boulders } \\
\text { Boulders }\end{array}$ \\
\hline $09 / 94$ & $\begin{array}{l}\text { Grevenmacher } \\
\text { Grevenmacher }\end{array}$ & $\begin{array}{l}211.2 \\
211.2\end{array}$ & $\begin{array}{c}\text { Channel } \\
\text { Right Bank }\end{array}$ & $\begin{array}{l}65909 \\
17563\end{array}$ & $\begin{array}{l}0 \\
0\end{array}$ & $\begin{array}{l}20012 \\
35634\end{array}$ & $\begin{array}{l}\text { Boulders } \\
\text { Boulders }\end{array}$ \\
\hline $07 / 94$ & $\begin{array}{l}\text { Hauconcourt } \\
\text { Hauconcourt } \\
\text { Hauconcourt } \\
\text { Hauconcourt }\end{array}$ & $\begin{array}{l}287.5 \\
286.5 \\
286.3 \\
286.3\end{array}$ & $\begin{array}{l}\text { Left Bank } \\
\text { Left Bank } \\
\text { Right Bank } \\
\text { Left Bank }\end{array}$ & $\begin{array}{r}19358 \\
1311 \\
9759 \\
702\end{array}$ & $\begin{array}{r}142 \\
363 \\
1690 \\
8760\end{array}$ & $\begin{array}{r}925 \\
12 \\
166 \\
41\end{array}$ & $\begin{array}{c}\text { Cobbles } \\
\text { Gravel/small pebbles } \\
\text { Gravel/small pebbles } \\
\text { Coarse sand/fine gravel }\end{array}$ \\
\hline $09 / 94$ & $\begin{array}{l}\text { Hauconcourt } \\
\text { Hauconcourt } \\
\text { Hauconcourt } \\
\text { Hauconcourt }\end{array}$ & $\begin{array}{l}287.1 \\
286.9 \\
286.7 \\
286.1\end{array}$ & $\begin{array}{l}\text { Left Bank } \\
\text { Right Bank } \\
\text { Left Bank } \\
\text { Right Bank }\end{array}$ & $\begin{array}{l}2671 \\
7423 \\
3073 \\
2813\end{array}$ & $\begin{array}{r}5535 \\
545 \\
3382 \\
5019\end{array}$ & $\begin{array}{r}245 \\
32 \\
0 \\
52\end{array}$ & $\begin{array}{c}\text { Coarse sand/fine gravel } \\
\text { Sand } \\
\text { Coarse sands/fine gravel } \\
\text { Pebbles }\end{array}$ \\
\hline
\end{tabular}

Table II. - Location and density of Corbicula sp. (ind. $\mathrm{m}^{-2}$ ) sampled in the French part of the Mosel River betrween Sierck-lès-Bains (pK 242.5) and Gondreville (pK 367.0) according to the substrate type (winter period). pK corresponds to navigation kilometric point.

\begin{tabular}{|c|c|c|c|c|c|}
\hline Date & Station & pK & $\begin{array}{l}\text { Transversal } \\
\text { location }\end{array}$ & $\begin{array}{l}\text { Density of } \\
\text { Corbicula } \\
\text { (ind. } \mathrm{m}^{-2} \text { ) }\end{array}$ & Substrate \\
\hline $11 / 94$ & Sierck-lès-Bains & 242.5 & $\begin{array}{l}\text { Left Bank } \\
\text { Channel } \\
\text { Right Bank }\end{array}$ & $\begin{array}{r}0 \\
49 \\
1659\end{array}$ & $\begin{array}{c}\text { Cobbles } \\
\text { Gravel and cobbies } \\
\text { clay }\end{array}$ \\
\hline $11 / 94$ & Cattenom & 256.0 & Left Bank & 54 & Gravel/small pebbles \\
\hline $11 / 94$ & Cattenom & 258.0 & $\begin{array}{l}\text { Left Bank } \\
\text { Channel } \\
\text { Right Bank }\end{array}$ & $\begin{array}{r}22 \\
0 \\
6\end{array}$ & $\begin{array}{c}\text { Cobbles } \\
\text { Mud and boulders } \\
\text { Mud }\end{array}$ \\
\hline $11 / 94$ & Bousse & 276.5 & $\begin{array}{l}\text { Left Bank } \\
\text { Channel } \\
\text { Right Bank }\end{array}$ & $\begin{array}{r}34 \\
0 \\
20\end{array}$ & $\begin{array}{l}\text { Pebbles and cobbles } \\
\text { Cobbles and boulders } \\
\text { Pebbles and cobbles }\end{array}$ \\
\hline $11 / 94$ & Metz & 298.5 & $\begin{array}{l}\text { Left Bank } \\
\text { Channel } \\
\text { Right Back }\end{array}$ & $\begin{array}{r}70 \\
126 \\
0\end{array}$ & $\begin{array}{l}\text { Gravel and pebbles } \\
\text { Gravel/small pebbles } \\
\text { Cobbles and boulders }\end{array}$ \\
\hline $12 / 94$ & Dieulouard & 337.0 & $\begin{array}{l}\text { Left Bank } \\
\text { Channel } \\
\text { Right Bank }\end{array}$ & $\begin{array}{l}0 \\
7 \\
5\end{array}$ & $\begin{array}{l}\text { Mud and cobbles } \\
\text { Gravel and pebbles } \\
\text { Gravel and pebbles }\end{array}$ \\
\hline $12 / 94$ & Gondreville & 367.0 & $\begin{array}{l}\text { Left Bank } \\
\text { Channel } \\
\text { Right Bank }\end{array}$ & $\begin{array}{l}0 \\
0 \\
0\end{array}$ & $\begin{array}{c}\text { Cobbles } \\
\text { Gravel and pebbles } \\
\text { Pebbles and cobbles }\end{array}$ \\
\hline
\end{tabular}


small pebbles and clay substrates (respectively 126 and 1,659 ind. $\mathrm{m}^{-2}$ ).

\section{CONCLUSIONS}

The immigration of Corbicula sp. and Corophium curvispinum in the Mosel River is recent and the biogeographical area of those new invasive species is probably not stabilized in the North-East part of the France. It should furthermore be pointed out that Corophium curvispinum intrusion has had a strong impact on the zoobenthic community structure in the Rhine River (Paffen et al., 1994). Consequently, the structure and the dynamics of the benthic macroinvertebrate communities of the Mosel River must be now carefully observed.

\section{REFERENCES}

Berly A., 1989. Distribution spatio-temporelle des peuplements macrobenthiques prélevés par dragage dans une station du Haut-Rhône. Thèse de doctorat: Univ. Lyon I: $309 \mathrm{p}$.

Den Hartog C., Van Den Brink F.W.B. \& Van Der Velde G., 1992. Why was the invasion of the river Rhine by Corophium curvispinum and Corbicula species so successful? J. Natur. Hist., 26 : 1121-1129.
Dhur G. \& Massard J.A., 1995. Etude historique et faunistique des invertébrés immigrés ou introduits dans la Moselle luxembourgeoise et ses affluents. Bull. Soc. Nat. luxemb., 96 : 127-156.

Haesloop U., 1992. Establishment of the Asiatic clam Corbicula cf. fluminalis in the Tidal Weser River (N. Germany). Arch. Hydrobiol., 126(2) : 175-180.

Hebert P.N.D., Muncaster B.W. \& Mackie G.L., 1989. Ecological and genetic studies on Dreissena polymorpha (Pallas): a new mollusc in the Great Lakes. Can. J. Fish. Aquat. Sci., 46 : 1587-1591.

Kinzelbach R., 1991. Die Körbchenmuscheln Corbicula fluminalis, Corbicula fluminea und Corbicula fluviatilis in Europa (Bivalvia: Corbiculidae). Mz. naturw. Arch., $29:$ 215-228.

McMahon A.F., 1983. Ecology of the invasive pest bivalve Corbicula: 505561. In: W. D. Russel-Hunter (ed.) : The Mollusca: Ecology, Vol. 6. Academic Press Inc., New-York.

Paffen B.G.P.. Van Den Brink F.W.B., Van Der Velde G. \& Bij De Vaate A.. 1994. The population explosion of the amphipod Corophium curvispinum in the Dutch Lower Rhine. Wat. Sci. Tech., 29(3) : 53-55.

Van der Velde G., Paffen B.G.P. \& Van Den Brink F.W.B., 1994. Decline of zebra mussel populations in the Rhine: competition between two mass invaders (Dreissena polymorpha and Corophium curvispinum). Naturwiss., 81 : 32-34.

Schöll F., 1990. Zur Destandssituation von Corophium curvispinum Sars im Rheingebiet. Lauterbornia, $5: 67-70$.

I. () I: I S - J E A N

avenue d'Embrun, 05(x)3 GAP cedex

Tél. : (14.92.53.17.0)

Dépiot légal 83 - Janvier 1997

Imprimé en France 